Мялковська, Людмила. «Мовний образ Києва у текстах І. С. Нечуя-Левицького». Лінгвостилістичні студії, вип. 10, 2019, с. 114-124.

Mialkovska, Liudmyla. “The Linguistic Image of Kyiv in the Texts of I. S. Nechui-Levytskyi”. Linguostylistic Studies, iss. 10, 2019, pp. 114-124.

УдК 811.161.2' 38

https://doi.org/10.29038/2413-0923-2019-10-114-124

\title{
МОВНИЙ ОБРАЗ КИЄВА У ТЕКСТАХ І. С. НЕЧУЯ-ЛЕВИЦЬКОГО
}

\author{
Людмила Мялковська \\ Луцький національний технічний університет, \\ Луцьк, Україна
}

У статті зроблено спробу змоделювати за художніми текстами I. C. НечуяЛевицького мовний образ Києва другої половини XIX - початку XX ст. Конкретизовано простір міста Києва власними назвами - топонімами, назвами сакральних споруд, детально описано пейзажні картини, виявлено типові епітетні, метафоричні структури, зафіксовано прагматично-оцінну семантику феномену «місто Київ», у якій поєднано візуальні картини з пізнавально-історичною інформацією.

Ключові слова: мовна особистість І.С. Нечуя-Левицького, творча спадщина письменника, мовний образ, пейзаж, історія української літературної мови.

Mialkovska Liudmyla. The Linguistic Image of Kyiv in the Texts of I. S. NechuiLevytskyi. The article attempts to outline the linguistic image of Kyiv in the second half of the $19^{\text {th }}$ and the beginning of the $20^{\text {th }}$ centuries in the artistic texts of I. S. Nechui-Levytskyi. Analyzing a particular word Kyiv, as well as the attributive phrase St. Kyiv, the old great Kyiv, the old city in the texts under the analysis, we revealed the expansion of the artistic-figurative paradigm of the linguistic image.

In the created linguistic portrait of the city, the lexical-associative connections used for the conceptualization of the general concept of "beauty" in the expression Kyiv-beauty city is semantically significant. The writer uses this expression when it is necessary to convey the positive impressions of the description of the urban space. Fascinated by the beauty of the evening Kyiv landscape, I. S. Nechui-Levytskyi writes about «a huge round rotunda temple», «a temple rich in paints and colors of nature», "a world gallery of paintings by a weird artists», "a gallery of paintings and views». These individual poetic associations fill the writer's artistic prose style with hues of celebration and exaltation.

The structure of the linguistic image of city plays a significant role in the landscape. Expanded landscapes described by I.S. Nechuy-Levytskyi, as a rule, intensify the trivial syntactic connection, which combines the names of urban realities such as monasteries, churches, baths, crosses, monuments and names of spatial notions of alley and mountains into a holistic contemplative picture.

In the studied works, the specific verbal images that have rich factual content, are the key and conceptual issues for the creation of the language image of Kyiv. These are architectural and sacral buildings: the monument to Prince Volodymyr, the St. Andrew's Cathedral, the Lavra, the Sofia, the Desyatinna and others.

It has been found out that in the descriptions of Kyiv there are often comparisons with golden bouquets, as well as epithetic phrases used with a bunch of golden flowers (about

(C) Мялковська Л., Східноєвропейський національний університет імені Лесі Українки, 2019.

Це стаття відкритого доступу на умовах СC BY-NC 4.0 
church baths), golden bouquets of the baths and crosses. The writer sees the entire space around through the prism of unearthly beauty, imposes the net of something fantastic and unreal on the picture of nature.

Key words: linguistic identity of I. S. Nechuyi-Levytskyi, creative heritage of the writer, linguistic image, landscape, history of the Ukrainian literary language.

Вступ. У 70-х рр. минулого століття в популярному на той час громадсько-політичному і літературно-мистецькому тижневику «Україна», що видавався в Києві, журналіст М. Мандрика писав про I.С. НечуяЛевицького: «Він увічнив старий Київ» (12). Підставою для такого висновку були оригінальні художні описи міста, які зберігають ознаки часу, коли жив письменник, а також особливості його індивідуального стилю.

Наші сучасники навіть не здогадуються, що Київ у художніх текстах I. С. Нечуя-Левицького виконує роль неодмінного складника художньої оповіді. Саме в Києві розгортається дія багатьох творів письменника. Герої I. С. Нечуя-Левицького здобувають освіту в Києві, їдуть туди вирішувати адміністративні питання, відвідують драматичний театр, оперу, магазини, дізнаються про новинки моди. До Києва йдуть на церковні служби, готуючись до сповіді та причастя, персонажі тих творів, у яких автор описує життя села та простого люду («Баба Параска та баба Палажка», «Микола Джеря», «Кайдашева сім'я»). Пригадаймо «Кайдашеву сім'ю» і те враження, яке справив на Мелашку Київ, коли вона 3 прочанами на Великому тижні ходила туди, щоб висповідатися: <...> Мелашка стояла, мов кам'яна. Ті золоті верхи та білі дзвінищі здавалися для неї якоюсь дивною казкою (Нечуй-Левицький 3: 376); Краса міста, краса церков, монастирів одібрала од неї [Мелашки] думку навіть про Лавріна (НечуйЛевицький 3: 82).

Сприймання, розуміння творчої спадщини I. С. Нечуя-Левицького - це постійний процес: сучасні дослідники прочитують твори письменника в нових суспільних умовах. Очевидно, час накладає нові вимоги і розкриває нове прочитання творчості письменника. Тому можна говорити про нове бачення нашими сучасниками творчості I. C. Нечуя-Левицького.

Так, наприклад, літературознавець М. Тарнавський у монографії «Нечуваний Нечуй» (2018) створює індивідуалізований портрет I. С. НечуяЛевицького, називає його «неприхованим українським патріотом», «центральною постаттю української літератури пошевченківської доби». У творах письменника дослідник простежує описи міста, урбаністичного простору i тим самим заперечує поширену в українському літературознавстві думку про письменника як етнографа села (етнографічного реаліста). Пор.: «Нечуй одним із перших в українській літературі описав місто, де розгортається дія багатьох його творів, проте читачі зазвичай не завважують, скільки для нього значив Київ» (Тарнавський 60). Що ж до штучно створеного в радянському літературознавстві образу I. С.Нечуя-Левицького як етнографа села 
(етнографічного реаліста) М. Тарнавський дає такий коментар: «Історики літератури раз по раз називають Нечуя етнографом села й «літописцем побуту», але його сільські краєвиди - це радше естетичне замилування оперного співака у відпустці, ніж практичний погляд трударя, котрий ціле життя орав землю. У Нечуєвій Україні вдосталь мальовничих пейзажів і замало пшеничних ланів. Село - це сузір'я хаток довкола церкви, декоративний елемент, не переобтяжений сільськогосподарськими відомостями, краєвид без конкретики» (92).

Мета дослідження полягає в конкретизації мовного образу Києва другої половини XIX - початку XX ст. за художніми текстами I. С. НечуяЛевицького.

Матеріал і методи дослідження. Мовний образ Києва досліджено за текстами таких творів I. С. Нечуя-Левицького: «Хмари», «Ніч на Дніпрі», «Апокаліпсична картина в Києві», «Дивовижний похорон», «Вечір на Владимирській горі».

У дослідженні використано метод лексично-структурного аналізу, що унаочнює авторське візуальне сприймання міста через фіксацію власних і загальних назв, пов'язаних із топонімом Київ, а також через характеристику лексики різної граматичної структури; метод типології кольороназв для виявлення особливостей авторського стилю у змалюванні пейзажу, метод лексико-семантичних і лексико-асоціативних зв'язків для концептуалізації загального поняття «краса»; прагматичнооцінний аналіз тексту для окреслення міфологічних уявлень письменника у мовному зображенні Києва.

Результати дослідження. У художніх текстах І. С. Нечуя-Левицького назва Київ - це одне із частотних слів: зафіксовано 1067 конкретних слововживань.

У художньому баченні І. С. Нечуя-Левицького Київ постає як святе, старе велике [місто], тобто місто, що має давню історію, на що вказують уживані в контексті лексеми споконвіку, пам'ятку, минувшість, пор. у тексті: Стоять київські гори непорушно <...>, як і споконвіку, несуть на собі пам'ятку про минувшість для того, хто схоче їі розуміть, і ждуть не діждуться, поки знов вернеться до їх слава старого великого Києва<...> (Нечуй-Левицький 2:6); Забачивши святий Київ, вони [тульські семінаристи] зареклися більще пити, щоб вступити по-християнській до святого міста (Нечуй-Левицький 2: 6).

В описах Києва, його сакральних споруд часто з'являються порівняння із золотими букетами, а також епітетні словосполучення букет золотих квіток (про церковні бані), букети золотоверхих церков, золоті букети з бань та хрестів. Увесь навколишній простір письменник бачить крізь призму неземної краси, накладає на картину природи мережу чогось фантастичного та нереального. Напр.: <...> на горах було видно Київ, що неначе потопав в легкій прозорій імлі. Забудування неясно мріли в сизій далечі, а над ними були розкидані ніби золоті букети: то лисніли 
позолочені бані та хрести на монастирях та церквах. Та далека картина здавалась якимсь квітником з золотими маківками та золотими квітками, за які розказують тільки в казках. I високе та глибоке синє іюньське небо, і ті далекі сизі шпилі й гори з Андріївським собором на чолопочку шпиля, і золоті букети з бань та хрестів - усе це було схоже на ті вигляди, що часом сняться у сні, що за їх розказують в казках. Вік проживеш - і не забудеш за цю пишну картину <...> (Нечуй-Левицький 8: 189). Пор. також: Саме проти їх стояла Лавра, обведена білими високими мурованими стінами та будинками, й лисніла золотими верхами й хрестами, наче букет золотих квіток (Нечуй-Левицький 2: 6).

Для створення образної картини Києва, письменник використовує епітети-колоративи червоний, зелений, червонястий, золотий, позолочений, рожевий, сизий, фіолетовий, а також іменникову та дієслівну лексику на позначення кольоровияву - тон, блиск, одлиск, кольори, темнішати/ потемнішати, посинішати, лисніти. Головною дійовою особою у таких пейзажних описах виступає сонце та його проміння, пор.: Сонще вдарило зза лісу червоним промінням на київські гори. Широка зелена Оболонь $i$ Поділ вкрились тінню й потемнішали. Виразніше виступили високі смужки київських гір під ясним чистим небом, обсипані збоку червонястим промінням. Тисячі вікон в домах, позолочені хрести та бані на церквах ніби зайнялись і запалали.

Од їх посипались наче пучки золотих стрілок. На дзвіницях неначе горіли червоним золотом хрести та маківки, наче плавали високо-високо понад горами в синьому небі, ніби линули якісь казкові золоті птиці. $<\ldots>$

Сонце спустилось ще нижче над лісом і почало ніби ховаться десь в сизих борах. Оболонь, луки й Поділ ніби тонули в тінь ще глибше. Київські сизі гори стали фбіолетові. <...> Усе облилось делікатними фіолетовими одлисками. За Києвом і за Дніпром небо од низу темнішало, посинішало й лисніло легеньким фіолетовим одлиском. <...> Кольори на Києві згасали (Нечуй-Левицький 8: 190).

I. С. Нечуй-Левицький пробуджує в уяві читача зорові, конкретночуттєві образи-картини не тільки за допомогою слів - носіїв кольористичної семантики, але також і за допомогою слова здавалось, яке означує, що «саме в уяві ті чи ті реалії набувають певних рис, властивостей» (Бибик 51). Напр.: Вигляд на Київ став якийсь фантастичний. Здавалось, ніби на горах з'явивсь і мрів пишний міраж, сплетений з чудових тонів, з блиску, з золота, з рожевої імли та сонячного проміння (Нечуй-Левицький 8: 190]. Словесний образ Києва, що грунтується на зіставленні його 3 пишним міражем, мотивований характерними для індивідуального стилю письменника міфологічними уявленнями (Єрмоленко, «Оновлений український» 128). Можливість міфологічного сприймання ключового для авторського тексту образу закладена також і в слові фантастичний. 
Мовна естетика словесного живопису письменника, а також характерних для його індивідуального стилю висловлювань на зразок: <..> я <...> побачив такий вигляд, таку красу, яку рідко коли трапляється побачить над Дніпром (Нечуй-Левицький 9: 72); Яка краса! Якими прикрасами багата природа закрасила прегарний Київ! (Нечуй-Левицький 9: 91) має в своїй основі формулу «прекрасне в природі». Пор.: «Глибший аналіз естетичного споглядання прекрасного в природі показав, що ми насправді можемо споглядати природу як досвідчені й художньо розвинені люди» (Гадамер 77). Показовий щодо цього опис вечірнього київського пейзажу, який споглядає автор, перебуваючи на Володимирській горі. Пор. у тексті: Виходжу я над самісінькі кручі, глянув униз, $і$ - над самісіньким Подолом знов побачив іниу таку чудову картину, якої, може, нема й по всій Росії, з такими оригінальними тонами й сутінками, що я аж зчамрів з дива. <...> ввесь Поділ вже горить огнями, розкиданими по місті до самої Почайни. Он горять електричні білі огні довгими рівними рядками по великій улищі <...>. Он берег Дніпра в закругленій гавані та коло пристанів неначе облямований смужкою з ярих білих ліхтарів. Посередині Подолу ніби горять червоно-жовті написи над сінематографами. $A$ подекуди блискають, мов червоні зорі, червоненькі огні в вікнах домів, розкидані вередливими чудними взорцями, поплутаними в чудному безладді. На довгому рядку пароходних пристанів в ятках, поставлених на суднах, лиснять прегусто червонуваті дрібні, ніби огняні, цятки та плямки, густо скуплені, неначе зірки на небокрузі. Ця червоняста смуга червоніє, мов торочки чорного покривала. По Дніпрі на пароходах знов миготять в вікнах на воді червоні вогні, неначе на смузі розтопленого олива. А ондечки, ще далі вгору, на безмежному темному просторі десь блискають малесенькі огні, певно, на пароходах або на плотах на Дніпрі та на Десні. <...> Я довго милувався цією величністю картини, яку довелось мені бачить вперше на віку. Яка краса! Якими прикрасами багата природа закрасила прегарний Київ! Недурно ж письменники звуть Київ городом-красунем <...> (Нечуй-Левицький 9: 91). У цьому тексті словесний мегаобраз краси, яку зумів відчути письменник, дивлячись на чудову панораму вечірнього Києва (пор.: знов побачив іншу таку чудову картину, якої, може, нема й по всій Росї; милувався цією величністю картини, яку довелось мені бачить вперше на віку), «підпорядкований ідеї переконати читача, що він живе в особливій країні», це «аргумент на захист європейської України» (Бибик 54). Ця думка втілена і в такому висловлюванні автора: Яка пишна ця широка картина! Кращої од неї трудно знайти $і$ по всій Європі (НечуйЛевицький 9: 88).

Захоплюючись красою вечірнього київського пейзажу, I. С. НечуйЛевицький пише про «велетенський круглий храм-ротонду», «храм багатющої на фарби й кольори натури», "світову виставу картин якогось дивного художника», «галерею картин та виглядів», "золотий палач 3 вікнами з діамантів та з золотими банями в царівни Паризади». Ці 
індивідуальні поетичні асоціації надають стилістиці художньої прози письменника певної урочистості та піднесеності. Прикладом може слугувати такий контекст: <...> в моїй уяві неначе все манячіли недавні гарні вигляди та картини, часом виникали з такою виразністю з усіма дріб'язковими частками, неначе я бачив їх перед собою уявки. I мені все здавалось, що я був в якійсь картинній превеликій галереї, надивився на усякові великі й невеликі картини та пейзажі, утворені з такою штучністю та художністю, з такою невимовною красою, якої я ще й досі не бачив. Мабуть, були великі естети наші давні київські князі, коли вони вибрали це саме місце над горамидля свого житла й для молитви перед тутечки ж поставленим Перуном (Нечуй-Левицький 9: 94).

Письменник наголошує на суголосності динамічного життя природи і фізичного та внутрішнього стану людини (одпочиваючих людей), і в таких паралелях виявляються особливості авторського бачення і сприйняття чудового київського пейзажу. Напр.: I на горах, і в природі, і в масі натовпу скрізь тихо й тихо, неначе ці одпочиваючі люде були щось одно сукупне й суцільне з чудовою природою навкруги, неначе й вони злучились $і$ злились 3 нею докупи. Я нігде не чую не тільки гаму й гармидеру од натовпу, не чую навіть човгання та шарудіння черевиків по шорстких доріжках та цегляних, міцних, як камінь, тротуарах. Серед цього натовпу можна залюбки й довго вдивляться в красу виглядів, можна милуватися, думати і навіть задумуваться й почувать, як у храмі, сповненому народом. $Я$ бачу тільки ворушіння людей по всіх усюдах. I серед задуманої тиші $я$ примічаю, що й ия ніби й мертва краса природи ворушиться. Он унизу на терасі близенько од мене й проти моїх очей стримлять верхи тополь. $Я$ придивляюсь до їх, а їх м'які довгі гілки ворушаться, ледве коливаються то в один бік, то в другий <..>. Он у самому низу кругом крутої гори дикі маслини <...>. Я придивляюся до їх, і вони помаленьку, ледве примітно усе коливаються, ніби хилитаються <...>. I це коливання ані шелесне, навіть не шамотить! ані шелесне, ані шамне ні одна гілочка! Мені здається, що то кидається пульс, кидається живчик дрімаючої й засипаючої краси живої природи (Нечуй-Левицький 9: 83-84).

Дослідники відзначають, що споглядання навколишньої природи викликає у письменника постійний образ килима, скатерті, шатра (Єрмоленко, «Оновлений український» 123), тому в його творах спостерігаємо пейзажні картини, побудовані на зіставленні навколишнього простору 3 килимом, а неба з шатром. Пор. художній опис розташованої поблизу Дніпра місцевості (нарис «Вечір на Владимирській горі»): Я бистро окинув оком незмірну плисковату рівнину по Оболоні за Подолом, понад Дніпром $і$ далеко за Дніпром по Десні й черніговських борах. Яка широчінь! Але ще не однотонна широчінь степів, або морів, або піскуватої пустині. Під лиснючим, помальованим усякими кольорами велетенським шатром ніби був розстелений квітчастий, без міри широкий килим. У мене в думці виникає уявлення, що то на долу в величезному храмі лежить розстелений 
килим. Який чудовий й різнотонний килим розгорнув і розіслав великий художник - натура під тим веселим, лиснючим, напнутим високо шатром! (Нечуй-Левицький 9: 73); Внизу ніби якась рука знімала з поцяцькованого суспіль дорогого килима його гарні кольорові прикраси; вони помаленьку й потроху зникали або все блякли й темнішали (Нечуй-Левицький 9: 76).

Звичними для «нічних» пейзажів I. С. Нечуя-Левицького $\epsilon$ інші метафоричні назви навколишнього простору, побудовані на асоціаціях його з полотнищем, оксамитом, сукном. При цьому часто повторювані епітети чорний, темний допомагають відтворити оригінальні зорові картини. Напр.: Перед моїми очима розстелялось ніби чорне велетенське полотнище чорного оксамиту, затканого й повишиваного огняними взорцями (Нечуй-Левицький 9: 91); Нанизу попід кручами знов я бачу темну ніч. Усей Поділ з будинками вже потонув в густій чорній темряві. Уся далека рівнина Оболоні, усі луки й луги на далекій Десні, і за Десною, і за Дніпром неначе вкрились чорним сукном (Нечуй-Левицький 9: 910; Усей Поділ був чорний та темний, неначе вкритий чорним оксамитом <..>. I в тій чорній темряві ніби висіли на повітрі різні електричні ліхтарі та червоніли осяяні світлом вікна в високих домах. Яке чудове чорне широке полотнище, усе неначе поцяцьковане, посипане й заткане ясними блискучими здоровими зірками, в вередливих чудернацьких, сливе фантастичних взориях (Нечуй-Левицький 8: 263).

Конкретно-предметні асоціації навколишньої природи 3 полотном з'являються і в такому контексті: Над самісіньким краєчком гори стояли рядками гуляючі люди й дивились на широку картину, котра полотном розстелялась сливе під самісінькими ногами (Нечуй-Левицький 2: 114).

Поряд із реальною конкретикою змісту слів килим, шатро, полотно, полотнище, оксамит, сукно, які залучає письменник для створення образної картини вечірнього та нічного Києва, свою функціональну роль виконують назви абстрагованого змісту на зразок безодня, простір (безмежний). Вони увиразнюють, підсилюють семантику безкрайого простору, пор.: Ні домів, ні церков, ні монастирів та вулиць - нічого не видко в темряві, неначе їх там і нема. Тихо-тихо! Тільки в тій чорній безодні ніби плавають в чорному повітрі скрізь по рівнині розсіяні й повішані ясні, білі, різкі, сливе соняшні огні та червонясті плями <...> (Нечуй-Левицький 8: 263); А десь далеко на Оболоні, десь аж коло Почайни, окроме од міста, біліють ярі білі електричні ліхтарі <...>. А ондечки, ще далі вгору, на безмежному темному просторі десь блискають малесенькі огні, певно, на пароходах або на плотах на Дніпрі та на Десні (НечуйЛевицький 9: 1).

Словесні картини Києва I. С. Нечуй-Левицький малює і за допомогою зорових, візуальних образів, які мають багатий фактографічний зміст. Так, автор неодноразово звертається до зображення пам'ятника князю Володимиру як до одного з основних символів Києва. Пор.: А прямо передо мною розстеляється вся подовжаста тераса, вкрита тінню й сутінками, 
вся ніби кучерява од дерева по алеях і по всій терасі, де стримлять гострими верхами гонкі тонкі тополі, ніби зелені свічки. Ясно, ніби під самими моїми ногами, жовтіє доріжка, що навкруги обрамовує тротуаром глибоку западину, ніби ярок над самим спуском. Ця глибока западина, чи яр, вже давно уся засаджена деревом, що густо розрослось на дні. Верховіття цього дерева вже виглядає на саму терасу. А по терасі знов видно кучеряве, скрізь розкидане дерево аж за пам'ятник. Я кидаю оком на пам'ятник $i$ звідсіль бачу його між двома тополями. Князь Владимир стоїть 3 хрестом, неначе в зеленому гаю, на самих вершечках дерева того гаю, неначе на зеленому живому п'єдесталі, і піднімає хрест вище од себе (Нечуй-Левицький 9: 81); Я озираюсь навкруги з цього високого пункту $i$ придивляюсь до цієї широкої картини, котра помаленьку все неначе тоне в тіні й сутінки скрізь по горах і западинах. I мені здалось, що я несподівано опинився серед лісів, серед діброви. <...> Попід стрімкою горою дерева на широкій довгій алеї сплелись докупи, мов у лісі. Пам'ятник так само неначе стоїть поверх лісу на зеленому верховітmі, а кругом його стримлять скрізь гостроверхі тополі. Дивлюся вниз, за спуском глибока й вузька долина, кудою спускаються по крутому покаті дерев'яні сходи до старого Владимирового пам'ятника, уся густо заросла деревами і по дні, $i$ по обидва круті боки. I тільки біла колона старого пам'ятника 3 капітеллю зверху та з золоченою маківкою й хрестом витикається високо вгору з зеленої гущавини, ніби з води здоровещька щогла затопленого корабля, а по обидва боки й за нею виникають велетенські осокори й тополі (Нечуй-Левицький 9: 81); Я подивився на правий бік од шпиля, за виступ, де на терасі стоїть пам'ятник св. Владимира. Там зеленіє попід горами ніби ліс. Ця тераса вся сливе суспіль засаджена деревом, з широкою алеєю попід самісінькою горою,з зеленими кружалами коло пам'ятника, де червоніють клумби квіток. Ця Владимирська тераса з верхньої гори здається старим зеленим лісом (Нечуй-Левицький 9: 77).

Змальовуючи конкретні візуальні картини Києва, письменник досить часто звертається до словесного образу київських гір: Останні поштові гроші вони [кандидати до академії] пропили в Броварах, недалечко од Києва, хрестячись і молячись до синіх святих київських гір, на котрих біліли церкви й дзвіниці, блищали проти сонця золоті хрести й бані церков (НечуйЛевицький 2: 6). Звертаємо увагу на семантичне наповнення й конотації епітетів синій, святий. Так, у семантиці прикметника синій варто вбачати не лише пряму віднесеність кольору до зображуваної реалії, а й асоціативний зв'язок з позитивними емоціями, з якими пов'язаний саме цей колір. Позитивну оцінку виявляє також прикметникове означення святий, яке у вислові-образі святі київські го́ри розкриває одне із своїх значень, пор.: Святий. 1.<..> // Уживається як постійний епітет до слів, пов'язаних із місцями або предметами релігійного поклоніння (Словник 9: 101-102). 
Епітетне поле номінації го́ри доповнюють і розширюють художні означення, які ідентифікують цю природну реалію за висотою та характером схилів. Наприклад, слововживання високі гори, семантика якого засвідчує зв'язок з просторовою орієнтацією, розкриває своє функціональне навантаження у контексті: На високих горах скрізь стояли церкви, дзвіниці, неначе свічі палали проти ясного сонця золотими верхами (Нечуй-Левицький 2: 6).

Поряд із висловом на високих горах скрізь стояли церкви, дзвіниці значення «зорове сприймання пейзажу, картини міста» характерне для синтаксичної конструкції високі гори, де блищали золоті верхи Михайлівського монастиря, де на шпилі висів собор Андреївський, в якій конкретизується певний простір, подається його детальна характеристика, пор. у тексті: I довго ще після молитви, сидячи перед одчиненим вікном, дивився Дашкович на сонний, тихий Київ, на високі гори, де блищали золоті верхи Михайлівського монастиря, де на шпилі висів собор Андреївський, а попід горою зеленіли садки, біліли стіни будинків (НечуйЛевицький 2: 19). Такий опис нічного Києва вимагає уповільненого зорового сприймання: увага зосереджується на динаміці дієслівних утворень - відприкметникових слів, якими письменник послуговується на позначення динамічної кольористики (пор. блищали, зеленіли, біліли).

Конкретно-чуттєве зображення гір досягається за допомогою лексично-синтаксичних засобів, в яких типова ознака кольору трансформується з прикметникової форми у дієслівну, прислівникову тощо. Така синтаксична метафора дозволяє об'єднати в споглядальній картині численні лексичні одиниці, що передають загальну семантику вияву кольору, та урізноманітнити форму відтворення зорових вражень. Пор.: Гори стоять дуже круті з ледве примітним покатом на терасу, але це вже не дикі стрімкі передніші кручі, а зелені, ніби зелено поgбарбовані або обстелені зеленим оксамитом. Нанизу вони на всю довжину ніби обкладені або обмальовані темно-зеленою смужкою: то зеленіють верхи дерев на двох алеях попід самісінькою горою вподовж тераси (НечуйЛевицький 9: 79). Якщо семантика епітетів стрімкий, крутий відбиває характер схилів гір (пор.: Стрімкий. 1. Майже прямовисний, крутий (Словник 9: 778); Крутий. 1. Майже прямовисний; стрімкий (Словник 4: 77)), то семантика епітета дикий, що означує слово кручі (лексеми го́ри і кручі $є$ синонімами), безпосередньо пов'язана із називанням вражень, психологічного сприйняття цієї природної реалії, напр.: Дикий. 1. <...>// Пустельний, глухий (Словник 2: 274).

Заквітчаний, заквітчати, квітки - це ті слова, які найчастіше супроводжують контексти з епітетом зелений. Актуалізацію зазначених слів пояснюємо тим, що в семантичній структурі кольороназви зелений реалізується «відтінок новизни, свіжості» (Єрмоленко, Нариси 73). Крім того, цей колір «асоціюється з радістю і ряснотою, теплом і яскравим сонячним світлом і містить елемент естетичної оцінки: мальовничий, 
такий, що милує око» (Яворська 47). Уведення названих лексем у словесні образи, у художній контекст робить їх характеристичними, семантично вагомими деталями пейзажного опису I. С. Нечуя-Левицького.

Функціонування лексеми го́ри у творах письменника засвідчує не тільки традиційне використання цієї назви в художньому пейзажному зображенні, а й уживання її у контекстах, в яких йдеться про авторське осмислення української історії. Стилістичної ваги у відповідних контекстах набувають слова із часовою семантикою. Пор. уривок: Всі гори були ніби зумисне заквітчані зеленими садками <...>. Їх заквітчала давня невмираюча українська історія, неначе рукою якогось великого артиста... Стоять київські гори непорушно, заглядають в синій Дніпро, як $i$ споконвіку, несуть на собі пам'ятку про минувшість для того, хто схоче її розуміть, і жуть не діждуться, поки знов вернеться до їх слава старого великого Києва, поки знов заквітчають їх потомки давніх батьків свіжими квітками історії... (Нечуй-Левицький 2:6). Час захоплює в орбіту своєї дії не лише історію, а й лексеми давній, невмираючий, споконвіку, пам'ятка, минувшість, старий, потомки, семантична структура яких імпліцитно містить компонент 'час'. Авторські метафори заквітчала історія, неначе рукою... артиста та свіжі квітки історії теж перебувають в асоціативно-семантичному полі «час». Причому обидві конструкції відбивають образне моделювання світу абстрактних понять. Так, у першій із наведених метафор спостерігаємо оживлення лексеми історія, тоді як метафоричний вислів свіжими квітками історії демонструє оречевлення відповідного абстрактного поняття через поєднання його 3 реалією природи.

Висновки та перспективи досліджень. Отже, у художніх творах I. C. Нечуя-Левицького мовну модель Києва другої половини XIX - початку $\mathrm{XX}$ ст. репрезентують власні назви - топоніми, словесні образи сакральних та архітектурних споруд, а також лексеми з кольоративною семантикою, порівняльно-метафоричні конструкції, метафори 3 певними типами асоціативних зв'язків, які виявляють особливості художнього мовомислення письменника. Структура мовного образу Києва в досліджуваних текстах I. С. Нечуя-Левицького постає як феномен зображеного конкретного простору, природного ландшафту, візуального, семантично-асоціативного та оцінно-почуттєвого змісту поняття «місто Київ». У дослідженні майстерності створених пейзажних картин перспективною $\epsilon$ тема виявлення контекстів, маркованих авторською модальністю оповіді.

\section{Список використаної літератури}

Бибик, Світлана. «„Та ніч, як Божий рай” (лінгвопоетика пейзажотворення у творі Івана Нечуя-Левицького „Ніч над Дніпром”)». Культура слова, вип. 79, 2013, с. 45-54. Гадамер, Ганс-Георг. Герменевтика і поетика. Київ: Юніверс, 2001.

Єрмоленко, Світлана. Нариси з української словесності (Стилістика та культура мови). Київ: Довіра, 1999. 
Єрмоленко, Світлана. «Ословлений український пейзаж і портрет у творах I. НечуяЛевицького». Мовно-естетичні знаки української культури. Київ, 2009, с. 11930.

Мандрика, Микола. «Він увічнив старий Київ». Україна, № 45, 1970, с. 12.

Мялковська, Людмила. «I. С. Нечуй-Левицький - культурник, етнограф, письменник». Українська мова, № 1, 2019, с. 138-50.

Мялковська, Людмила. «Місто у художньому просторі I. Нечуя-Левицького». Мова $i$ культура, вип. 14, т. 4, 2011, с. 330-6.

Нечуй-Левицький, Іван. Зібрання творів. У 10 т. Київ: Наукова думка, 1965-1967.

Словник української мови, за ред. І. К. Білодіда. В 11 т. Київ: Наукова думка, 1970-1980.

Тарнавський, Максим. Нечуваний Нечуй. Реалізм в украйнській літературі. Київ: Лаурус, 2018.

Яворська, Галина. «До проблеми формування європейської ідентичності в Україні». Наукові записки Інституту політичних $і$ етнонаціональних досліджень ім. I. Ф. Кураса НАН України, вип. 42, 2008, с. 269-77.

\section{References}

Bybyk, Svitlana. ““'Ta nich, yak Bozhyi rai” (linhvopoetyka peizazhotvorennia u tvori Ivana Nechuia-Levytskoho “Nich nad Dniprom”)”. Kultura slova, iss. 79, 2013, pp. 45-54.

Gadamer, Hans-Georg. Hermenevtyka i poetyka. Kyiv: Yunivers, 2001.

Yermolenko, Svitlana. Narysy z ukrainskoi slovesnosti (Stylistyka ta kultura movy). Kyiv: Dovira, 1999.

Yermolenko, Svitlana. "Oslovlenyi ukrainskyi peizazh i portret u tvorakh I. NechuiaLevytskoho". Movno-estetychni znaky ukrainskoi kultury. Kyiv, 2009, pp. 119-30.

Mandryka, Mykola. «Vin uvichnyv staryi Kyiv». Ukraina, no 45, 1970, p. 12.

Mialkovska, Liudmyla. "Ivan Nechuy-Levytskyj - Cultural, Etnographer, Writer". Ukrainska mova, no 1, 2019, pp. 138-50.

Mialkovska, Liudmyla. "Misto u khudozhnomu prostori I. Nechuia-Levytskoho". Mova $i$ kultura, iss. 14, 2011, pp. 330-6.

Nechui-Levytskyi, Ivan. Zibrannia tvoriv. 10 vols. Kyiv: Naukova dumka, 1965-1967.

Slovnyk ukrainskoi movy, edited by I. K. Bilodid. 11 vols. Kyiv: Naukova dumka, 1970-1980.

Tarnavskyi, Maksym. Nechuvanyi Nechui. Realizm v ukrainskii literaturi. Kyiv: Laurus, 2018.

Yavorska, Halyna. "Do problemy formuvannia yevropeiskoi identychnosti v Ukraini". Naukovi zapysky Instytutu politychnykh i etnonatsionalnykh doslidzhen im. I. F. Kurasa NAN Ukrainy, iss. 42, 2008, pp. 269-77. 